\title{
GENOMIC DNA ISOLATION AND QUANTIFICATION IN VARIOUS ECORACES OF TASAR SILKMOTHS ANTHERAEA MYLITTA. D
}

\author{
Sreenivas Manda \\ Department of Zoology, Kakatiya University, \\ Warangal-506009, Telangana, India
}

\author{
Shamitha Gangupantula \\ Department of Zoology, Kakatiya University, \\ Warangal-506009, Telangana, India
}

\author{
Renuka Gattu \\ Department of Zoology, Kakatiya University, \\ Warangal-506009, Telangana, India
}

\begin{abstract}
Antheraea mylitta, a lepidopteran insect, producing tasar silk, is wild in nature and is commercially exploited in almost nine states of tropical India. It shows variation in its phenotypic traits like cocoon weight, silk ratio and also in fecundity and voltinism. Their populations found in different areas are known by their specific local names and are considered as different ecotypes, but it is difficult to separate them on the basis of morphological and life-cycle traits and thus molecular characterization was done. The present study depicts the genomic DNA isolation and quantification in the different ecoraces of tasar silkworm, $A$. mylitta. The DNA was extracted using phenol-chloroform- isoamyl alcohol and the quantification of the extracted DNA was analysed using agarose gel.
\end{abstract}

Key words: Antheraea mylitta, phenotypic traits, ecotypes, quantification, DNA extraction, agarose gel.

\section{INTRODUCTION}

Tasar silk is mentioned in 1590 B.C. The various genera of family Saturnidae, to which Tasar Silkworm belongs, are Antheraea hubner (Oriental region), A. pernyei (China, Japan and USSR), A. yamamai (Japan), A. proylei (India) and Antherea mylitta (India and Tropical countries). Lepidopterans are accepted as ecological indicators of ecosystem healt, Hilty et al. (2000). They are used as models because of their amount of modifications in their community structure; they react quickly to environmental changes and they are considered to be the umbrella species and indicators of habitat quality. It has also been confirmed that a decrease in habitat leads to a decrease in species diversity and abundance and an alteration of Lepidopteran community composition Steffan-Dewenter et al. (2002).

Tasar silkworm, Antheraea mylitta Drury, is a sericigenous, polyphagous insect distributed in the form of about 43 ecoraces in varied geographical tropical zones in India Singh et al. (1997), like Bihar (Singhbhum, Santhal), Madhya Pradesh (Jagdalpur), Orissa (Mayurbhanj), West Bengal (Bankura), Maharashtra (Bhandara), Andhra Pradesh, Telangana (Adilabad, Warangal, Karimnagar and Khammam) and Karnataka (Belgaum). Among fifty races of sericigenous insects 25 races of A.mylitta. D alone is seen Jolly et al. (1974).

The Indian tasar silkworm, A.mylitta is a natural fauna of tropical India, distributed in different geographical locations and habitats in this country. Possibly, because of the distinct ecological conditions prevailing in these different localities, several morphological variants, traditionally called ecoraces Arunkumar et al. (2015).

Modification of DNA Isolation protocol is useful to involve larger populations and representatives encompassing various regions of our country for phylogenetic studies, and evolve future breeding programme of Andhra local ecorace as a strategy to conserve the dwindling population which is on the brink of extinction Renuka et al. (2016). This study also useful for genetic diversity of tasar ecoraces, selected parental ecoraces and F1 and F2 hybrid populations, as revealed by co-dominant markers helps the prospective breeders in the development of disease resistant, high yielding tasar populations and contribute towards their conservation Sreenivas et al. (2018). 
The first and foremost step in undertaking any such molecular work is the extraction of quality DNA from the desired sample Wani et al. (2013). In case of insects including Silkworm, the best source of DNA for molecular study is fresh/live insects

The genomic DNA from 13 ecotypes and inbred lines of Bombyx mori were analysed by digesting with Bst NI and HinFI followed by hybridization with Bkm probe 2(8) Najaraju et al. (1995). The DNA fingerprinting of silkworms revealed 9-31 discrete intense bands, some of which were ecotype or inbred-line specific. The isolation of intact, highmolecular mass genomic DNA is essential for many molecular biology applications including PCR, endonuclease restriction digestion, Southern blot analysis and genomic library construction Nagaraju, Furdui et al. (2001, 2014)

The present study depicts genomic DNA isolation and quantification in various ecoraces of tasar silk moth, A. mylitta. The DNA was extracted from these ecoraces by phenol-chloroform Isoamyl alcohol (24:24:1) extraction and the purity and concentration of the extracted DNA was analysed for further studies.

\section{MATERIALS AND METHODS}

a. Collection of wild cocoons of various Tasar silkworms

Collection of wild cocoons viz., Andhra local ecorace from Warangal district (Telangana); Daba $\mathrm{TV} \& \mathrm{BV}$ ecoraces from Adilabad, Khammam, Telangana districts (Telangana); Bhandara ecorace from Bhandara (Maharasthra), Sukinda from Sukindergarh (Orissa), Raily from Bastar (Chhatisgarh) and Modal from Baripada district (Orissa). The ecoraces from distant ecopockets of country were collected by exploring the natural habitats Fig 1, 2 and Table 1).

For the present study, the economically important ecoraces of Tasar silkworm, viz.,Daba, Sukinda, Raily, Modal, Bhandara, and Andhra local were collected from their natural habitat, labelled in falcon tubes and were maintained in the germplasm bank of Kakatiya University, Warangal for conducting genomic studies.

\begin{tabular}{|c|l|l|}
\hline S.No & Ecorace & \multicolumn{1}{|c|}{ Site of collection } \\
\hline 1 & $\begin{array}{l}\text { Andhra } \\
\text { local }\end{array}$ & Warangal,Telangana \\
\hline 2 & Daba TV & $\begin{array}{l}\text { Warangal,Khammam,Adilaba } \\
\text { d Telangana. }\end{array}$ \\
\hline 3 & Daba BV & $\begin{array}{l}\text { Warangal,Karimnagar, } \\
\text { Telangana }\end{array}$ \\
\hline 4 & Modal & Baripada, Orissa \\
\hline 5 & Sukinda & Sukindagarh, Orissa \\
\hline 6 & Raily & Bastar, Chhatisgarh \\
\hline
\end{tabular}
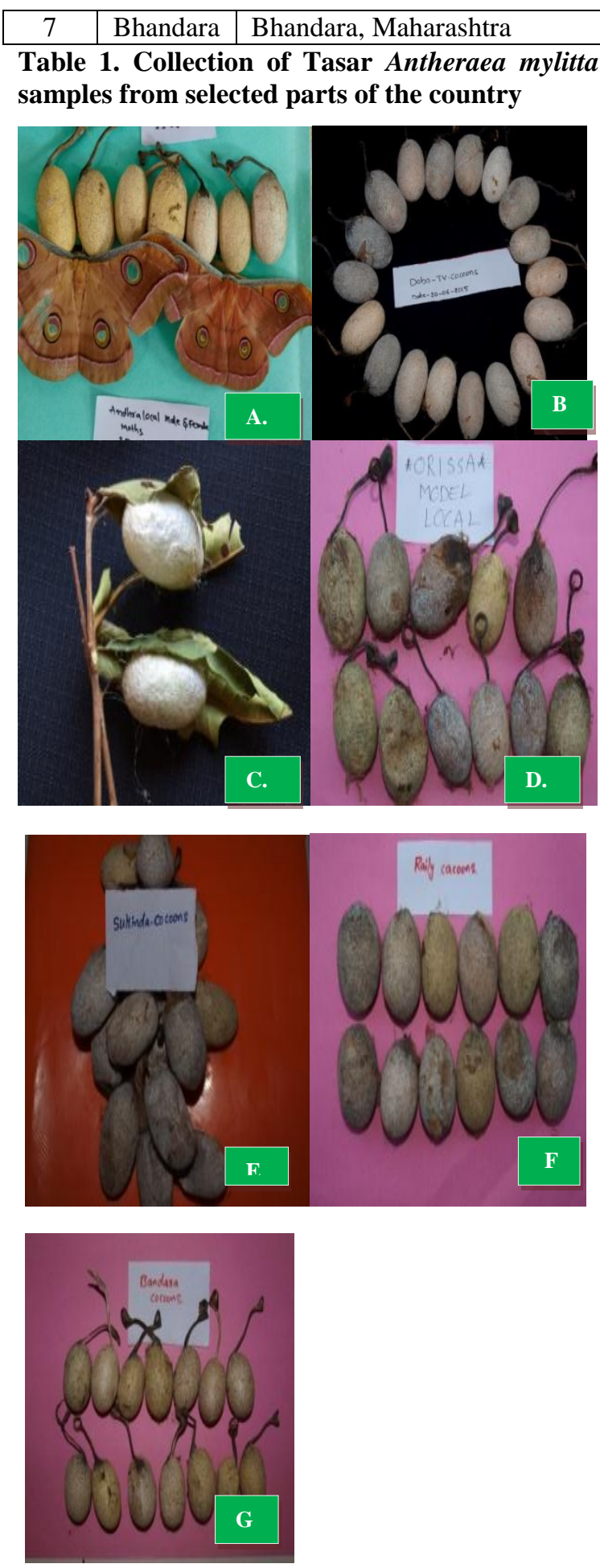

Fig.1 Cocoons of various tasar ecoraces- (A-G) Andhra local, Daba TV, Daba BV, Modal, Sukinda, Raily and Bhandara 


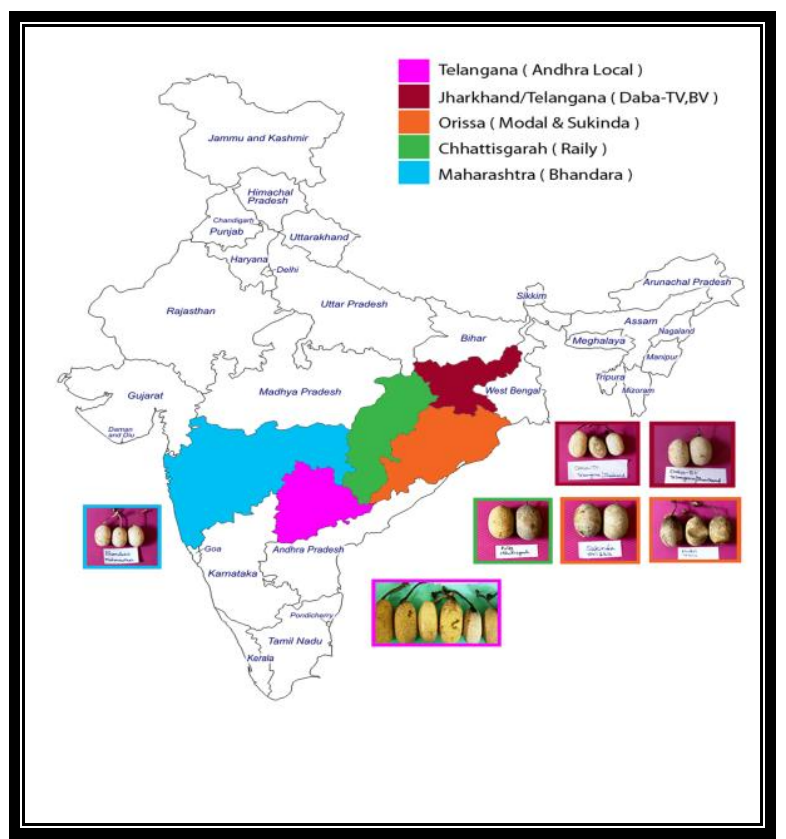

Fig.2. Collection of Tasar A. mylitta samples from selected parts of the country Sreenivas et al. (2017)

\section{b. Isolation of Genomic DNA}

Genomic DNA was extracted from randomly selected individual moths from each generation of each line and the control group by the use of the phenol-chloroform method Suzuki et al. (1972), later it was modified by Najaraju et al. (1995). Genomic DNA isolated from adult silk moths of tasar silkworm A. mylitta of various ecoraces. The wings, legs and antennae of moths were cut with sterile scissors before isolation process.

1. From each of seven tasar ecoraces, 13 randomly selected silkmoths were taken and frozen with liquid nitrogen and homogenized with the help of pestle and motor ground till fine powder.

2. The content was taken in $2 \mathrm{ml}$ microfuge/autoclaved tubes containing 5 $\mathrm{ml} 2 \mathrm{PK}$ buffer (Lysis buffer) and $25 \mu \mathrm{l}$ of proteinase $\mathrm{K}(100 \mathrm{mg} / \mathrm{ml})$.

3. The samples were mixed well to incubate overnight @ $37^{\circ} \mathrm{C}$ in incubator shaker (model Wise Cube).

4. Next day the tubes were taken out from incubator shaker and added equal volume of saturated phenol using glass pipette and the tubes were mixed gently by inversion.

5. The samples were centrifuged @ 10,000 rpm for 15 minutes at $4^{\circ} \mathrm{C}$. The supernatant was collected in a clean autoclaved centrifuge tube using $1 \mathrm{ml}$ pipette.
6. Equal volume of Phenol: Chloroform: Isoamyl alcohol (24:24:1) were added and mixed by inversion and centrifuged @ 10,000 rpm for 20 minutes. The upper aqueous phase was transferred into fresh autoclaved tubes.

7. An equal volume of Chloroform was added to it, mixed gently and centrifuged @ 10,000 rpm for 20 minutes. The upper aqueous phase was transferred into fresh autoclaved tubes and immediately kept at $20^{\circ} \mathrm{C}$ for 10 minutes.

8. To it was added $1 / 10^{\text {th }}$ volume of ice cold $3 \mathrm{M}$ Sodium acetate (pH5.2) and 3 volumes of ice cold absolute alcohol and the tubes were mixed gently by inversion and stored @-20 ${ }^{\circ} \mathrm{C}$ for 30 minutes.

9. Next the samples were taken from $-20^{\circ} \mathrm{C}$ again mixed gently by inverting tubes slowly and precipitate the DNA.

10. The tubes were spun @5000 rpm for 5 minutes and washed in $200 \mu \mathrm{l}$ of $70 \%$ alcohol. The tubes were spun at 10,000 rpm at $4^{\circ} \mathrm{C}$ for 10 minutes and the supernatant was discarded.

11. The pellet was air dried for about 20 minutes at room temperature.

12. After the pellet dried completely, $50 \mu 1$ of TE buffer and $50 \mu \mathrm{l} / \mathrm{mq}$ were added and allowed to dissolve completely in the buffer, so that the DNA is uniformly dissolved in the buffer.

13. Then, $1 \mu 1$ of DNA was loaded in $0.8 \%$ of agarose gel.

14. If RNA smear was seen in the gel then RNase was added the process was repeated from step 6-12.

\section{c. Preparation of $0.8 \%$ Agarose gel}

1. The amount of agarose needed was weighed into 250-ml Erlenmeyer flask, to make $100 \mathrm{ml}$ of $0.8 \%$ gel. To it was added $100 \mathrm{ml}$ of $1 \mathrm{X}$ TBE gel running buffer. The level of liquid in the flask was marked on the outside of the flask. A plug was placed loosely in the opening of the flask. The solution was kept in microwave to dissolve the agarose completely; the flask was swirled occasionally to mix. The height of the liquid level was checked in the flask. If necessary, sterile distilled water was added to bring the liquid back to the original level. The dissolved agarose was allowed to cool to about $45-50{ }^{\circ} \mathrm{C}$ before pouring the agarose into a gel 


\section{International Journal of Engineering Applied Sciences and Technology, 2019 \\ Vol. 4, Issue 4, ISSN No. 2455-2143, Pages 295-300 \\ Published Online August 2019 in IJEAST (http://www.ijeast.com)}

casting tray with appropriate comb to make the gel wells. The gel was allowed to solidify. It took 15-20 min, depending on the agarose concentration. When using the microwave, it was made sure to use autoclave gloves to pick up hot flasks.

2. Once the gel was solidified, the comb was removed from the gel. When removing the comb, care was taken not to tear holes in the wells formed. To aid in removing the comb, a small amount of $1 \mathrm{X}$ TBE was poured to running buffer around the comb before loosening the comb.

3. The gel was transferred from the gel tray to the gel tank. 1X TBE running buffer was added to cover the gel completely.

d. Genomic DNA quantification by spectrophotometeror / Nanodrop.

The purity and the concentration of the extracted DNA was analysed using spectrophotometer or Nanodrop. A pure solution of double-stranded DNA at $50 \mu \mathrm{g} / \mathrm{ml}$ has an optical density of 1.0 at $260 \mathrm{~nm}$ and an $\mathrm{OD}_{260} / \mathrm{OD}_{280}$ ratio of 1.8 . Contamination with protein or phenol will give $\mathrm{OD}_{260} / \mathrm{OD}_{280}$ values significantly less than 1.8 and contamination with RNA gives a ratio greater than 1.8 (For pure RNA, $\mathrm{OD}_{260} / \mathrm{OD}_{280}=2.0$ ). Thus, the $\mathrm{OD}_{260} / \mathrm{OD}_{280}$ value was obtained first, and, if it approaches 1.8, an accurate estimation of DNA concentration was determined from the absorption at $260 \mathrm{~nm}$.

e. Quantification of DNA in various Tasar Silkworm, A.mylitta using Gel Electrophoresis.

The quantification of Tasar Silkworm, A. mylitta, was done in 13 samples of each of the seven tasar ecoraces. The DNA mixture was loaded on $1.2 \%$ agarose gel in Tris-Boricacid/EDTA buffer (10X TBE $\mathrm{pH}$ 8.0) and electrophoresis was carried out with a constant voltage of $50 \mathrm{~V}$ in electrophoresis unit. Gel was stained with ethidium bromide $(0.5 \mu \mathrm{g} / \mathrm{ml})$, it runs for $2-3 \mathrm{hrs}$ on 50 volts and photographed with a Gel Documentation Unit (model no12 200069, 230V capacity) and the images were stored digitally on the attached computer (with specific software installed) in JPJ format. DNA samples were prepared in micro centrifuge tubes to be loaded on the gel. $2.0 \mu \mathrm{l}$ of gel loading buffer and $2 \mu 1$ of MQ were added for every $2 \mu$ of DNA sample, making it to a total of 6 $\mu \mathrm{l}$ (Fig. 3).

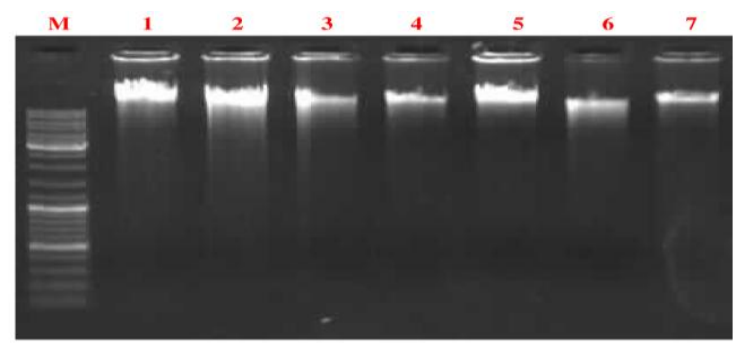

Fig: 3. Total genomic DNA isolation from different ecoraces of (A.L, D.TV, D.BV, Modal, Sukinda, Raily, Bhandara) tasar silkworm, $A$. mylitta. M. 1Kb DNA Ladder; 1.Andhra Local; 2.Daba TV; 3.Daba BV; 4. Modal; 5. Sukinda; 6.Raily; 7. Bhandara.

\section{RESULTS AND DISCUSSION}

\section{a. Isolation of Genomic DNA}

DNA isolation is one of the most basic and essential techniques in the study of DNA. The extraction of DNA from cells and its purification are of primary importance to the field of biotechnology and forensics. DNA extraction is required for a variety of molecular biology applications. Genomic DNA isolation involves disruption and lysis of the starting material followed by the removal of proteins and other contaminants and finally recovery of the DNA. Removal of proteins is typically achieved by digestion with proteinase $\mathrm{K}$, followed by saltingout, organic extraction, or binding of the DNA to a solid-phase support (either anion-exchange or silica technology).

One of the most commonly used and useful methods for isolation and concentration of DNA and RNA from aqueous solutions is phenol/chloroform extraction followed by ethanol precipitation. During organic extraction, protein contaminants are denatured and partition either with the organic phase or at the interface between organic and aqueous phases, while nucleic acids remain in the aqueous phase. Phenol used in this protocol is buffered to prevent oxidized products in the phenol from damaging the nucleic acids.

The present study is concerned with the phenol: chloroform method of genomic DNA isolation by using liquid nitrogen. The grinding of silkmoths under liquid nitrogen to fine powdered substance has yielded high resolution DNA bands by using phenol: chloroform extraction method.

Traditionally, Phenol: Chloroform is used to extract DNA, when phenol was mixed with cell lysate two phases were formed, viz., DNA to the (upper) aqueous phase and denatured proteins to the (lower) organic phase (Fig.4). 


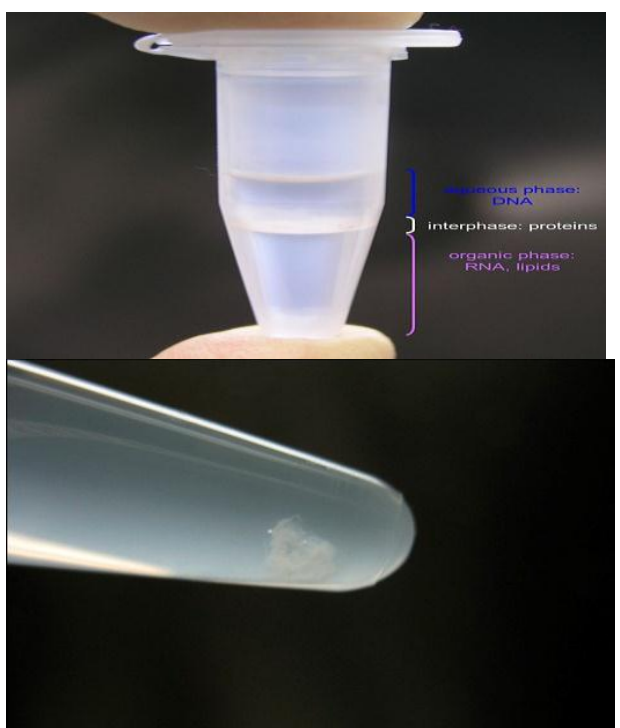

Fig.4 Phenol is mixed with cell lysate two phases form DNA partition to the (upper) aqueous phase denatured proteins partition to the (lower) organic phase

The concentration of proteinase-K was high, which extracted a high quantity of DNA. The main action of proteinase-K in extraction buffer was the removal of proteins which were attached to the DNA. RNase was used to remove RNA. The DNA obtained using this extraction protocol is suitable for molecular characterization, phylogenetic analysis, genetic variability, genetic diversity and breeding methods, involving various ecoraces of tasar silkworms Sreenivas et al. (2017).

DNA based marker technique opens up the avenue for the proper identification and selection of divergent silkworm breeds/strains that could be used in planning directional breeding programmes in modifying the yield potentials of temperate silkworms for quality bivoltine silk production Buhroo et al. (2016). The isolation of intact, highmolecular-mass genomic DNA is essential for many molecular biology applications including PCR, endonuclease restriction digestion, Southern blot analysis and genomic library construction Singh et al. (2011)

\section{b. Qualitative analysis of DNA}

The isolated DNA samples were exposed to $0.8 \%$ electrophoresis through agarose gel to measure the quality of DNA isolated from the various ecoraces of tasar silkworms under evaluation in the present study. The location of DNA within the gel was resolute directly by staining with low concentration of ethidium bromide $(10 \mathrm{mg} / \mathrm{ml})$ which acts as a fluorescent inserting dye. The gel was viewed under gel documentation system (UV light) to detect the quality of DNA. Presence of highly resolved high molecular weight sharp bands following the modified protocol indicated good quality DNA (Fig. 5).

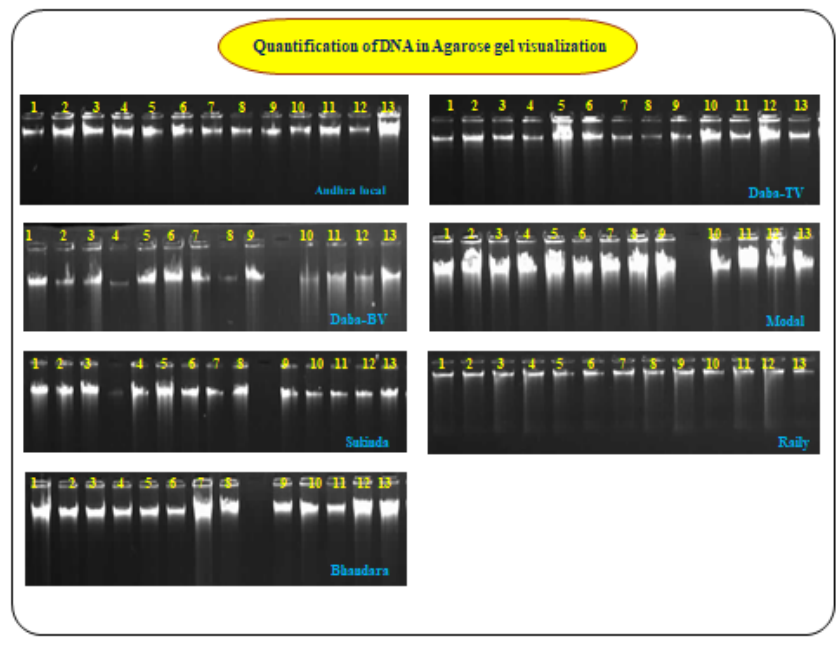

Fig 5: Total genomic DNA isolation from 7 ecoraces of tasar silkworm, $A$. mylitta. on $1.2 \%$ agarose gel visualization (1-13 represent individual strains of Andhra local, Daba-TV, Daba-BV, Modal, Sukinda, Raily, and Bhandara)

\section{c. Analysis of purity of DNA and Quantification}

The DNA isolation and the quantification of the various ecoraces of tasar silkmoths A. mylitta in the present study revealed an ideal concentration of DNA $n g / \mu l$ of the genomic sample (i.e., between the $1.6-1.8$ in 260/280 ratio) checked against $1 \mathrm{~kb}$ standard DNA ladder. It has been observed that DNA has been isolated without any protein or any other contamination and was used for further studies in PCR and phylogenic analysis (Table.2)

Table. 2 The DNA Isolation and the quantification of the 1-13 samples of various ecoraces Tasar Silkworm, A. mylitta - 1 Andhra local, 2 Daba-TV 3 Daba-BV 4 Modal 5 Sukinda 6 Raily 7 Bhandara.

\begin{tabular}{|l|l|l|l|l|}
\hline S.No & $\begin{array}{l}\text { Sample } \\
\text { name }\end{array}$ & $\begin{array}{l}\text { Concentrati } \\
\text { on } \mathrm{ng} / \mu \mathrm{l}\end{array}$ & $\begin{array}{l}260 / 2 \\
80 \\
\text { Ratio }\end{array}$ & $\begin{array}{l}260 / 2 \\
30 \\
\text { Ratio }\end{array}$ \\
\hline 1. & $\begin{array}{l}\text { Andhralo } \\
\text { cal }\end{array}$ & $188.3 \mathrm{ng} / \mu \mathrm{l}$ & 1.81 & 1.93 \\
\hline 2. & Daba TV & $816.6 \mathrm{ng} / \mu \mathrm{l}$ & 1.89 & 2.15 \\
\hline 3. & DabaBV & $135.4 \mathrm{ng} / \mu \mathrm{l}$ & 1.89 & 1.98 \\
\hline 4. & Modal & $178.1 \mathrm{ng} / \mu \mathrm{l}$ & 1.88 & 2.64 \\
\hline 5. & Sukinda & $399.0 \mathrm{ng} / \mu \mathrm{l}$ & 1.84 & 2.25 \\
\hline 6. & Raily & $298.8 \mathrm{ng} / \mu \mathrm{l}$ & 1.86 & 1.99 \\
\hline 7. & Bhandara & $389.6 \mathrm{ng} / \mu \mathrm{l}$ & 1.78 & 1.91 \\
\hline
\end{tabular}




\section{International Journal of Engineering Applied Sciences and Technology, 2019 Vol. 4, Issue 4, ISSN No. 2455-2143, Pages 295-300 \\ Published Online August 2019 in IJEAST (http://www.ijeast.com)}

\section{CONCLUSION}

The DNA was extracted from tasar ecoraces by phenol-chloroform- Isoamyl alcohol (24:24:1) method and an ideal concentration of the DNA were obtained. The present study depicts the genomic DNA isolation and its quantification has generated good amplifiable DNA bands which were found suitable for molecular study, phylogenetic analysis, genetic diversity, hybridisation and conservation of tropical tasar silkworm populations.

\section{ACKNOWLEDGEMENTS}

The authours are thankful to University Grants Commission (New Delhi), for providing funds required to carry out the present work under Major Research Project UGC/MRP: F No. 42528/2013 (SR), 22nd, March 2013).

\section{REFERENCES}

[1] Hilty., and Merenlender. (2000). Faunal indicator taxa selection for monitoring ecosystem health, Biological Conservation, (pp.185-197).

[2] Steffan-Dewenter, I., and Tscharntke, T. (2002). Insect communities and biotic interactions on fragmented calcareous grassland a mini review on Biological Conservation, (pp.275-284).

[3] Singh, B.M.K., and Srivastava, A.K. (1997). Ecoraces of Antheraea mylitta Drury and exploitation strategy through hybridization. Current Technology Seminar in Non-mulberry Sericulture. Base Paper 6, (pp.1-39).

[4] Jolly, M.S., Sen, S.K., and Ashan, M.M. (1974). Culture, Bombay: Ambika, (pp.1-166).

[5] Arunkumar, K. P., Nagaraju, J., and Jayaprakash, P. (2015). Genetic analysis of Indian tasar silkmoth (Antheraea mylitta) populations Scientific Reports, Doi: 10.1038/srep; 15728.

[6] Renuka,G., and Shamitha, G.(2016). Genetic variation in ecoraces of tropical tasar silkworm, Antheraea mylitta using SSR markers. Journal of Genetics, Vol. 95, No. 4.

[7] Sreenivas, M., Renuka, G., and Shamitha, G. (2018). Phylogenetic analysis of tasar ecoraces and hybrid populations as revealed through SSR markers. International Journal of Zoology and Applied Biosciences, (pp. 402-409).

[8] Wani., S, Bhat., M, Zafar., B, Ganai., M, and Majid., N.(2013). Role of molecular markers in silkworm improvement. International Journal of Recent Scientific Research. (pp. 515-523).

[9] Nagaraju., J, Balakarthiresan., S.A, Sethuraman., N, Rao., G.V, and Singh., L. (1995). DNA fingerprinting in silkworm Bombyx mori using banded krait minor satellite DNA-derived probe Seribiotech Laboratory, Bangalore, CCMB, Hyderabad, Electrophoresis, (pp.1639-1642).

[10] Nagaraju., J, Reddy., K, Nagaraja., G, and Sethuraman., B.(2001). Comparison of multilocus RFLPs and PCR based marker systems for genetic analysis of the silkworm, Bombyx mori, Heredity, (pp. 588 -597).

[11] Furdui., E, Marghitas., M, Dezmirean., D, Erler., S, and Schluns., E.(2014). Genetic Characterization of Bombyx mori (Lepidoptera: Bombycidae) Breeding and Hybrid Lines with Different Geographic Origins. Journal of Insect Science, 211(14), (pp. 1-6).

[12] Sreenivas., M, and Shamitha., G. (2017). Genetic diversity and phylogenetic relationship as revealed by inter simple sequence repeat (ISSR) polymorphism in the different ecoraces of Indian Tropical silkworm Antheraea mylitta Drury. International Research Journal of Biological Sciences Vol. 6(4), (pp.1-9).

[13] Suzuki., Y, Gage., L, and Brown., D.(1972). The genes for silk fibroin in Bombyx mori. J. Mol. Biol. 70, (pp. 637-649).

[14] Nagaraju, G.M, and Nagaraju., J.(1995). Genome fingerprinting of the silkworm Bombyx mori using random arbitrary primers. Electrophoresis, (pp.1633-1638).

[15] Sreenivas., Manda, and Shamitha., Gangupantula. (2017). Rearing Performance and Quantitative Assessment of F1 and F2 hybrids of Tasar Silkworm, Antheraea mylitta Drury. International Journal of Innovative Research in Science, Engineering and Technology, Vol. 6, Issue 9

[16] Buhroo., Z. I, Ganai., N. A, and Malik., M. A. (2016). An Efficient Protocol for Silkmoth DNA Extraction Suitable for Genomic Fingerprinting and Genetic Diversity Analysis. Journal of Cell and Tissue Research Vol. 16(3), (pp. 5921-5928).

[17] Singh., H.R, Unni., B.G, Neog., K, and Wann., S.B.(2011). Isolating silkworm genomic DNA without liquid nitrogen suitable for marker studies. African Journal of Biotechnology Vol. 10(55), (pp. 11365-11372). 